\title{
Gold in Antique Copper Alloys
}

\author{
Paul T. Craddock \\ Research Laboratory, The British Museum, London, U.K.
}

Lost continents, lost cities and fabulous materials from past ages have a natural fascination for scholar and layman alike. Since the Renaissance, men have sought examples of Corinthian Bronze, the precious alloy much extolled by ancient writers and have tried to establish its nature. As indicative of attitudes towards it, Thomas Corayte (1) described the bronze horses of San Marco in Venice as being 'a remarkable monument, four goodly brazen horses of Corinthian metal and fully as great as life', apparently for no better reason than that he thought such noble statuary demanded the most prized bronze metal of them all. Further, in Pliny's 'Natural History' (the Loeb edition, translated by Rackham (2), is referred to throughout this article), Book XXXIV, which is devoted to copper and bronze, begins with Corinthian Bronze which is referred to as 'valued before silver and almost even before gold'. In a later passage, in Chapter 3, Pliny writes as follows:

'Of the bronze which was renowned in early days the Corinthian is the most highly praised. This is a compound which was produced by accident when Corinth was burned at the time of its capture, and there has been a wonderful mania among many people for possessing this metal - in fact it is recorded that Verres, whose conviction Marcus Cicero had procured was, together with Cicero, proscribed for no other reason than because he had refused to give to Antony some pieces of Corinthian ware.'

Corinth was sacked by Roman forces under Mummius in 146 B.C. The implication is that in the fires which raged during the destruction of the city the constituent metals accidentally fused together.

Further on, Pliny discusses the appearance and composition of the alloy:

"There are three kinds of this sort of bronze, a white variety coming very near to silver in brilliance in which the alloy of silver predominates, a second kind in which the yellow quality of gold predominates and a third kind in which all the metals were blended in equal proportions. Besides these there is another mixture the formulas for which cannot be given although it is man's handiwork; but the bronze valued in portrait statues and others for its peculiar colour approaching the colour of liver, called by a Greek name 'hepatizon' meaning 'liverish' is a blend produced by luck; it is far behind the Corinthian blend.'

From this account we can deduce that the alloy was highly prized, and contained gold and silver, although presumably copper predominated as it was called bronze and was included in the copper section of the 'Natural History'. Many scholars, as early as Lempriere (3), have doubted its existence altogether, pointing out that no such alloy had been identified, and questioning what noticeable difference a few per cent of either gold or silver would make to the appearance of the copper. However, although we can accept the story of its accidental discovery two centuries before Pliny's time as apocryphal it is difficult to dismiss the latter's description of its popularity with collectors and its high value in his own time. It would seem that in Pliny's day the term Corinthian Bronze was used to describe a group of alloys which were readily distinguished and appreciated, and for which collectors were willing to pay a high price.

The first step towards recognizing surviving examples of this material was, of course, to have some idea of its appearance, Small quantitics of gold and silver incorporated in copper are known to have a dramatic effect on the resulting alloys if they are subsequently treated in a suitable manner. Thus, in Japan, treated alloys of copper with a little gold and silver were produced from early times until the twentieth century and are highly prized (Figure 1). A variety of alloy compositions and treatments gave a wide range of surface textures and colours. Amongst the most common and popular was the alloy known as shakudo, the manufacture of which has been recorded in detail by Gowland $(4,5)$ and Roberts-Austen (6). The processes which were used were complex, demanding great skill, and what follows is only a very brief summary of them. Shakudo was made from copper containing approximately 1 to 5 per cent of gold and 1 per cent of silver. According to Gowland, this was boiled in wood ash alkali, then steeped in a boiling saline solution of bitter plum juice vinegar, which is a source of acetic, malic and oxalic acids. Thereafter, the alloy was again treated with boiling wood ash alkali and then digested in a boiling copper acetate and sulphate solution, to which potassium nitrate might be added. This produced the much admired rich purple-black sheen on the alloy. The shakudo could then be inlaid with other surface-treated alloys or with gold, silver, brass or copper.

Silver-coloured alloys were made from alloys containing much more silver, such as obore-shirogane, or from alloys of copper and arsenic.

The only known alloys comparable in composition with Corinthian Bronze are thus very different from the mere debased gold or silver which the classical alloy was suspected of being. Pliny's description mentions colour only once, the silvery alloy being described as white, the other alloy as having the 'quality' of gold and the appearance of the third alloy being unspecified. Perhaps it is significant that the inferior, but comparable, alloy 'hepatizon' was liverish or purple in colour.

If Corinthian Bronze is to be understood as a family of surface-treated alloys similar to shakudo it must be asked if there is any reference to this process in classical literature. 


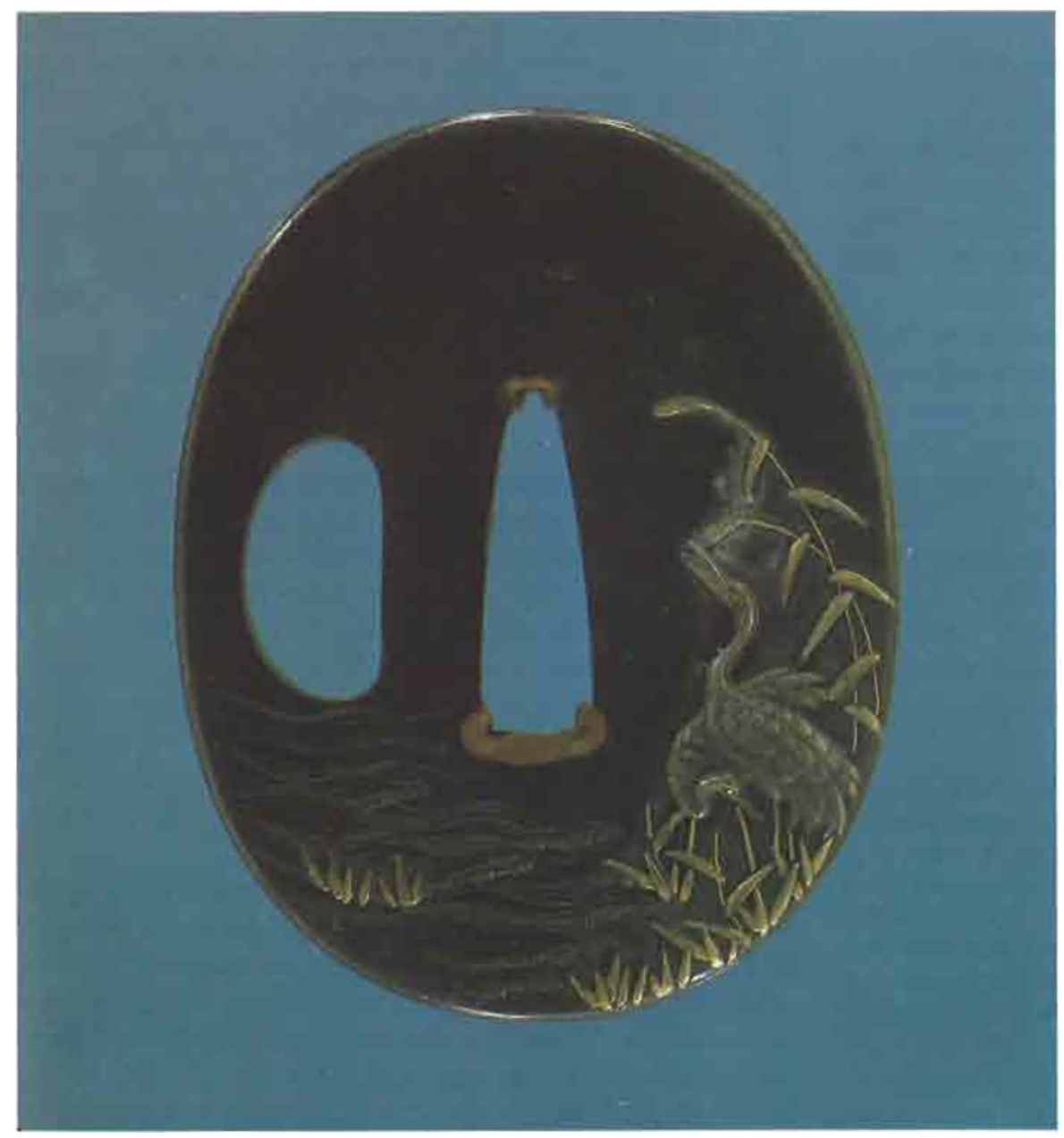

Fig. 1. Japanese sword guard (tsuba) of shakudo. British Museum, Oriental Antiquities OA 3432 Photograph by courtesy of the Trustces of the Brilish Museum

Here the answer is in the affirmative and the references can be found in the work of the alchemists. The Alexandrian alchemists were divided into those who attempted the transmutation of metals by alloying and those who employed surface treatments. One thing all alchemists had in common was their exasperatingly obscure terminology and vague description of processes, a fact readily verified by scholars attempting to follow the originals (Berthelot's translation (7) has been followed exclusively here). The process of iosis is frequently alluded to as a surface treatment. Generally, the term means 'rusting' but it does have the specific meaning of 'purpling' (Zosimus III, 56, 'On Vapours'). When applied, the process involved several colour changes from black through white, yellow, red and finally purple, strikingly similar to those in the shakudo process. Amongst the reagents mentioned by the alchemists, rhubarb is prominent and in one passage, Zosimus specifically states that the process of iosis is to be carried out with pimpernel and rhubarb, a rich source of malic, acetic and oxalic acids (Zosimus III, 16,
'Details of the Process') which would have an identical function to that fulfilled by the bitter plum vinegar in the Japanese process.

Further evidence from classical sources supporting this interpretation of the nature of Corinthian Bronze is to be found in Pausansias. In his description of 2nd century A.D. Corinth, he mentions the waters of the fountain of Peirene which were used in the treatment of Corinthian bronzes in a process then still operating there. This has been dealt with in detail by Caley (8).

The translation of the relevant passage is rather difficult. Fraser (9) translates it:

'... and they say that the so called Corinthian Bronze gets its colour by being plunged red hot into this water, for in point of fact Corinth has no bronze of its own.'

whéreas Jones (10) translates it as:

'... and they say that the Corinthian bronze when red hot is tempered by this water, since bronze ... the Corinthians have not.' 
The principal difficulty is the word $\beta a \pi \tau \varepsilon \Delta \theta a$ which Caley states "was often used by ancient authors ... to signify the dyeing of cloth and other materials and is even used in early Greek alchemical works with reference to gilding or silvering of metals. Moreover, the closely related verb $\varkappa \alpha \tau a \beta a \pi \chi \omega$ is used in the Leyden Papyrus X (11) to signify the dipping of base silver alloys in corrosive liquids for the purpose of changing or improving their surface colours.

However, in spite of numerous extant examples of these closely related uses there appears to be no actual example in the works of other authors of the use of the verb $\beta a \pi \tau \omega$ itself to denote the colouring of bronze or copper. From the ways in which $\beta a \pi \tau \omega$ is used by these other ancient authors, no certain confirmation exists that the word $\beta a \pi \tau \varepsilon \sigma \theta a l$ in the statement of Pausanias really implies that the bronze received its colour by dipping.

Caley rejected this interpretation because his experiments showed, that it was impossible to colour bronze with water from the Peirene fountain or any other natural waters, but it is also impossible to temper bronze by quenching in cold water so that the latter interpretation must be also discarded. The statement could make sense if we assume that the waters of the Peirene fountain were used to make the solutions used for treating Corinthian Bronze. This is far from being an entirely satisfactory explanation, but the brief statement of Pausanias does at least give further independent evidence that there was such a material as Corinthian Bronze, that surface treatment played a large part in its production and that it was still being made in Corinth in the 2nd century A.D.

So far this has been a story of possible interpretations and links, intangible and without evidence. However, the author of the present article had suspected that if Corinthian Bronze were to be found, it would prove to look like shakudo. After a search for material of this type, the Department of Conservation of the British Museum recently requested the Research Laboratory of the Museum to identify an unusual black deposit on a small Roman plaque which it had been asked to clean (Figure 2).

The deposit was analyzed and the presence in it of small amounts of gold and silver was established. Quantitative analysis of the body metal was undertaken by atomic absorption spectrometry. This showed its composition to be as shown in Table I.

The analytical method which was employed has been fully described by Hughes et al. (12) and the results have a precision of \pm 20 per cent. The detection limit for each element was 0.0005 per cent in the metal. The gold and silver contents of this alloy are at least a hundred fold greater than is normally encountered in Roman copper. The arsenic content is also high, and one cannot exclude the possiblity that it too

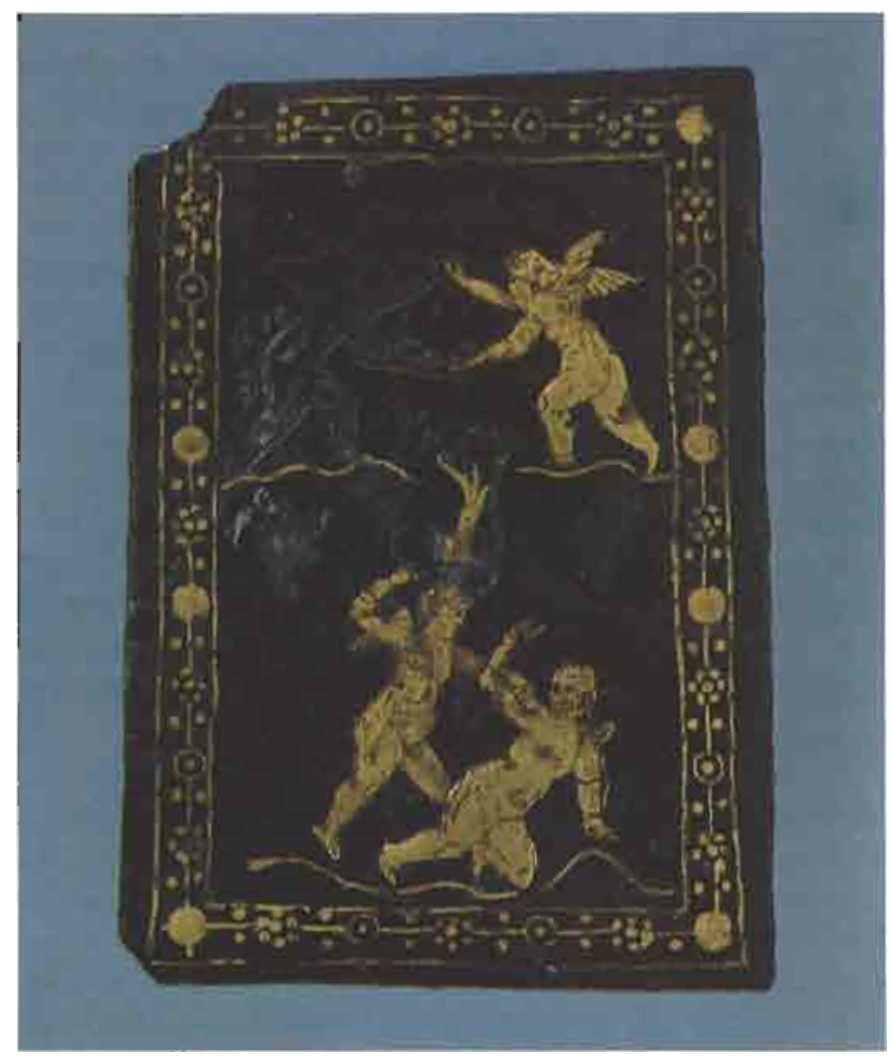

Fig. 2. Roman inlaid plaque of composition and surface treatment similar to those of shakudo. British Museum, Greek and Roman Antiquities Reg. No. 1979, 12-13, 1

Photograph by cottrtesy of the Trustees of the British Museum

is a deliberate addition, expecially as arsenic features strongly in both Japanese and Roman metallurgical and alchemical practices. The tin and lead probably derive from scrap bronze

Table I

Composition of the Body of a Roman Plaque

\begin{tabular}{l|c}
\hline \multicolumn{1}{c|}{ Metal } & Weight \% \\
\hline Copper & 92 \\
Gold & 0.6 \\
Silver & 1.2 \\
Tin & 1.4 \\
Lead & 1.9 \\
Arsenic & 1.1 \\
Antimony & 0.3 \\
Nickel & 0.3 \\
Zinc & 0.05 \\
Bismuth & 0.005 \\
Cadmium, manganese, iron & \\
$\quad$ and cobalt & not detected
\end{tabular}


which has been used as a source of copper.

The black surface of the plaque is uniform and dense, approximately $0.5 \mathrm{~mm}$ thick and of similar composition to the body metal. It is firmly bonded to the substrate but no trace of an organic binder could be detected by either infrared spectroscopy or the more mundane red hot needle test. This and the appearance of the surface when viewed through a microscope strongly suggested that it had formed in situ, and had not been applied. X-ray diffraction revealed only the presence of cuprite $\mathrm{Cu}_{2} \mathrm{O}$ as detected in shakudo by Notis (13). Cuprite is normally deep red, but here as in the Japanese pieces, the gold and silver finely distributed throughout the copper must, in a subtle manner, have changed and deepened the colour to the familiar purple black. Where some areas of inlay were missing it was observed that the patination extended into the channels, showing that the metal was treated before inlaying, as one would expect to have been the case.

The composition, appearance and even decorative treatment are so similar to those of the Japanese pieces that one is tempted to speculate on possible links, even through the thousands of years and across the great distances that would have been involved. Needham's work has repeatedly shown both the sophistication of science in ancient China and the important reciprocal influences of Oriental and Occidental sciences. More specifically, he suggests that shakudo may be the Chinese 'Purple Sheen Gold' so beloved of the Taoist alchemists from the Han Dynasty onwards (14). Significantly, one carly Chinese source noted by Needham (15) records that it was plentiful in Persia and the West and had been imported thence to China.

There is evidence of alloys of this type having been produced in Tibet at least until the 19th century. Most Tibetan images were of brass or copper (15), but Jigs-med-glin-pa (1729-1798) refers also to a more exotic product, dzne-ksim, which seems to have been a naturally occurring alloy, dark and of fine quality (16). However, it could be produced artificially from copper mixed with gold, silver and nickelsilver. Significantly, just after this account of a dark bronze was originally written, the English writer Turner (17) was travelling in Tibet and described the metal used in the images which he saw in the Bkjra-shis-lhunpo monastery. Concerning these he states:

'Some of the images were composed of that metallic mixture which in appearance rescmbles Wedgewood's black ware but the greater part were of brass or copper gilt.'

It is tempting to identify the 'metallic mixture resembling Wedgewood black ware' with the contemporary description of $d z n e^{-k} k$ sim and suggest this as evidence for the operation of a shakudo style process in Tibet. It will be necessary to find and examine a surviving piece of $d z n e-k s i m$ before the validity of this suggestion can be tested and verified.

In the 20th century, research into ancient science and technology has repeatedly demonstrated that many important processes and ideas originated in the East, and not in the West as previously thought. It would be a welcome change to be able to show that one of the most oriental of techniques could well have its origins in Hellenistic Greece, while at the same time providing new evidence of the close links and interdependence of scientific and technological development throughout the Old World.

\section{References}

1 T. Corayte, 'Thomas Coraytes' crudites hastily gobbled up in five months travel in France, Savoy, Italy, Rhetia Commonly called the Grisons Country, Helvetia alias Switzerland, high Germany and Netherlands W'William Stansby, London, 1611

2 H. Rackham, 'Pliny. Natural History', vol. 9, Loeb edition, Heinemann, London, 1968, especially pp. 127 and 131.133

3 J. Lempriere, 'A Classical Dictionary', 7 th edition, Codell and Davies, London, 1809 , especially p. 216

$4 W$. Gowland, 'Japanese Metallurgy I', J. Soc. Chem. Ind., 1896, 15, especially p. 484

5 W. Gowland, 'Metals and Metalworking in Old Japan', Trans. Jpn. Soc London, 1915, 13, 20

6 W.C. Roberts-Austen, 'Alloys', J. R. Asiat. Soc, 1888, 36, especially pp. 1111,1125 and 1137

7 M. Berchelot, 'Collection des Anciens Alchimistes Grecs', Steinheil, Paris, 1888

8 E.R. Caley, 'The Corroded Bronze of Corinth', Proc. Am. Pbilos. Soc. $1941,8,(5), 689-761$ and especially pp. 749-751

9 J.G. Frazer, 'Pausanias' Description of Greece Translated with a Commentary', vol. 1, Macmillan, London, 1898, cspecially p. 74

10 H.L. Jones, 'Pausanias' Description of Greece with an English Translation', vol, 1, Loeb edition, Heinemann, London, 1918, especially p. 261

11 R. Halleux, 'Les Alchimistes Grecs', Tome I, Papyrus de Leyde, Papyrus de Stockholm, Fragments de Recettes, Soc, d'edition 'Les Belles Lettres', Paris, 1981

$12 \mathrm{MJ}$. Hughes et al., 'Atomic Absorption Techniques in Archaeology', Archaeometry, $1976,18,19-37$

13 M.R. Notis, 'Study of Japanese Mokume Techniques by Electron Microprobe Analysis', MASCA Journal, 1979, 1, (3), 67-69

14 P.T. Craddock, "The Copper Alloys of Early Tibet and Related Metalwork', in 'Aspects of Tibetan Metallurgy', edited by W.A. Oddy and V. Zwalf, British Museum Occasional Paper no. 15, London, 1981

$15 \mathrm{~J}$. Needham, 'Science and Civilization in China', vol. 5, Part 2, Cambridge University Press, London, 1972, especially pp. 23 and $257-266$

16 L.S. Dagyab, 'Tibetan Religious Art. Part 1, Texts', Harrasowitz, Wiesbaden, 1977, especially Chapter 21

17 S. Turner, 'An account of an embassy to the Teshoo Lama in Tibet', G. and W. Nicol, London, 1800 , especially p. 274 